\title{
The influence of smoking cessation, regular physical exercise and/or physical activity on survival: a 13 years cohort study of the Indonesian population in Jakarta
}

Dede Kusmana

\begin{abstract}
Abstrak
Mencegah proses aterosklerosis dengan membiasakan tidak merokok/stop merokok disertai olahraga teratur dan/atau pengaruh kerja fisik (trias SOK) adalah upaya preventif di masyarakat. Untuk mengetahui pengaruh trias SOK terhadap daya survival, dilakukan penelitian kohort historis pada sampel MONICA 1988 di tiga kecamatan Jakarta Selatan, serta diikuti sampai 31 Agustus 2001. Sampel dibagi menjadi kelompok trias SOK dan tanpa trias SOK. Dilakukan wawancara faktor risiko (merokok, hipertensi, hiperlipidemia, diabetes, obesitas), pemeriksaan fisik, laboratorium dan perekaman EKG. Otopsi verbal untuk mencari sebab kematian. Aktivitas fisik dikelompokkan pada: tidak ada, ringan hampir setiap hari, sedang dan berat minimal 20 menit dua kali atau lebih. Analisis statistik: regresi Cox, Kaplan Meier, Log rank, uji kappa, batas kemaknaan p<0,05. Terdapat 479 (23,4\%) sampel dari 2073 orang, umur 25-64 tahun (1988), terdiri dari 209 (43,6\%) lelaki, 270 (56,4\%) perempuan. Insiden kardiovaskular 1,2\% pertahun, proporsi kematian penyakit jantung 42,9\%. Daya survival sampel trias SOK lebih baik (95,7\%) dibanding tanpa trias SOK (81,1\%), (HR 0,20, 95\% IK 0,08-0,57, p=0,002]. Aktivitas fisik mempunyai rasio kematian rendah [ringan HR 0,45, IK 0,27-0,76, p=0,003), sedang (HR 0,32, IK 0,15-0,70, p=0,004) dan berat nol] dibanding tidak ada.Rasio kematian merokok tinggi (HR 4.99,KI 2.56-9.73, p=0,000), Dihasilkan Skor Kardiovaskular Jakarta, Skor -7 sampai 1 risiko rendah (<10\%), skor 2 sampai 4 sedang (10-20\%), skor $\geq 5$ risiko tinggi (>20\%). Upaya pencegahan penyakit kardiovaskular dengan cara tidak/stop merokok, dikombinasikan dengan olahraga teratur dan/atau kerja fisik merupakan cara tepat untuk meningkatkan daya survival. Dihasilkan Skor Kardiovaskular Jakarta untuk memprakirakan kematian kardiovaskular di masyarakat. (Med J Indones 2002; 11: 230-41)
\end{abstract}

\begin{abstract}
Preventing atherosclerosis with smoking cessation, regular physical exercise and/or physical activity known as $S O K$ (S-top/ no $S$ moking, sp-O-rt/ physical exercise, wor-K/ physical activity) is a simple preventive measure, which can be applied in the community. To determine the role of SOK on survival, to create cardiovascular risk score for Indonesian patients and to have a special formula to predict survival. A historical cohort study over thirteen years recruited from the subpopulation MONICA patients who resided at three districts of South Jakarta. Patients were divided into two groups, those with SOK and those without (non-SOK group). Assessment included complete history including cardiovascular risk factors (hypertension, diabetic, hyperlipidemia, obesity), physical examination, laboratory examination, twelve-lead ECG recording and level of physical activity/exercise. Outcomes included survival rate and all-cause of mortality. Statistical analysis included kappa statistic and various survival analyses. 479 participants were included in the SOK study. Mean age 46 years (range 25-64), 56\% female. Cardiovascular mortality rate (including stroke) was $1.2 \%$ per year and $42.9 \%$ of mortality caused by heart disease. Survival rate was higher in SOK group compared with non-SOK (95.7\% vs 81.1\%) with Hazard Ratio (HR) 0.2 for SOK group (95\% CI 0.08$0.57, p=0.002)$ In relation to the cardiovascular mortality rate: 1) any physical activity/exercise (OK) vs no-OK will lower the risk; low-OK (HR 0.4, $p=0.003)$, medium-OK (HR 0.32, p=0.004), high-OK (HR 0.000, $p=0.000)$ 2) Smoking will increase the risk vs non-smoking (HR 4.99, $p=0,000)$. For predicting the cardiovascular events in ten-year time $\left(C V^{10}\right)$, we formulated the Jakarta Cardiovascular Score. The score was divided into low-risk (-7-1) with $C^{10}<10 \%$, average-risk $(2-4)$ with $C V^{10}=10$ $20 \%$, high-risk (score $\geq 5$ ) with $\mathrm{CV}^{10}>20 \%$. Smoking cessation, regular physical exercise and/or physical activity is an effective method to reduce cardiovascular death, thus enhances the survival. We formulated a simple method to predict cardiovascular events in our community known as the Jakarta Cardiovascular Score. (Med J Indones 2002; 11: 230-41)
\end{abstract}

Keywords: smoking, physical activity, survival, Jakarta cardiovascular score.

Department of Cardiology, Faculty of Medicine, University of Indonesia / National Cardiovascular Center "Harapan Kita", Jakarta, Indonesia 
Data obtained from World Heart Federation revealed that mortality rate from cardiovascular disease in developed countries had decreased from $51 \%$ in 1985 to $46 \%$ in 1997 , but in developing countries it had increased from $16 \%$ in 1985 to $24 \%$ in $1997 .{ }^{1}$ In Indonesia, data from Research and Development Centre/Department of Health had shown that the cardiovascular mortality rate increased from $5.9 \%$ in 1975 to $19 \%$ in $1995 . .^{2,3}$

Endothelial dysfunction, at the beginning of atherosclerosis, correlated well with multiple cardiovascular risk factors such as hereditary, hyperlipidemia, hypertension, diabetes, smoking, obesity, physical inactivity and stress. ${ }^{10}$ Elevated plasma fibrinogen, homocysteinemia, elevated serum lipoprotein (a) [Lp(a)] and chlamydia infection have emerged as new risk factors. ${ }^{11-12}$ Controlling the modifiable risk factors (smoking, diabetes, obesity and physical activity) will delay atherosclerosis and will reduce the cardiovascular events including stroke. ${ }^{13-17}$

Recent finding has shown that by increasing blood flow as much as $4 \mathrm{mls}$ for at least 2 minutes, especially if pulsatile, will enhance nitric oxide production and promote endothelial relaxation of the arterial vessel. ${ }^{18,19}$ At rest, coronary flow is about 200 $\mathrm{mls} / \mathrm{minute}$ ( $4 \%$ of stroke volume). This flow will increase to $350 \mathrm{mls} /$ minute during low exercise with heartbeat of 110 per minute. With medium and high intensity level of exercise, the coronary flow will doubled, with the heartbeat of 130 or more per minute. $^{20-22}$ Regular physical exercise (sport) or physical activity will increase the heartbeat and coronary flow, and if performed 2 to 3 times weekly for at least 20 minutes will prevent endothelium from atherosclerosis.

The preventative measure utilizing smoking cessation, regular physical exercise and physical activity abbreviated as SOK (S-top S-moking, regular sp-O$\mathrm{rt} /$ physical exercise, wor-K/physical activity) will delay endothelial dysfunction. Thus, survival rate will increase. To estimate the load of physical activity, the Borg-sport scale is used because it is simple to obtain; by asking one's perception during exercise. The scale correlated well with oxygen consumption. ${ }^{23}$ Low level of physical exercise/activity, which is equal to less than five Mets, cause no burden and no respiratory or heartbeat alteration to the person. Medium level of physical exercise/activity, equal to 5-7 Mets, causes moderate burden, moderate increase of the heartbeat, moderate increase of the respiratory rate and moderate increase of sweating ("looking for sweat"). Whereas, high level of physical exercise/activity, more than 7 Mets, gives the person heavy burden feeling, his heartbeat and respiratory rate will increase significantly and he will sweat profusely ("bathing in sweat").

A developing country like Indonesia, which is currently in a financial crisis, requires a simple measure for preventing cardiovascular disease. SOK is a simple method, which easily can be implemented to the Indonesian community. The abbreviation, SOK, is also easy to remember. It should be effective since Indonesia has a high prevalence of smoking. Most people are lacking in sport and having low level of physical activity.

\section{METHODS}

SOK study is a historical cohort study over thirteen years. The participants were taken from the subpopulation of 1988 Jakarta-MONICA trial. Data were collected for twelve months, from July 2000 until August 2001. All patients recruited for the study lived in the districts of South Jakarta i.e. Mampang Prapatan, Kebayoran Baru and Cilandak. They were selected because they had a complete data and their data had been stored in the computer since the beginning of the MONICA study in 1988. The three districts, known as a laboratory community, were under Harapan Kita National Cardiovascular Centre supervision. Healthy-life campaign for the districts had been done since 1993 by the health personnel. They used leaflets/pamphlets and did home visits. In their campaign, they promoted the cease smoking program and encouraged the community to have a regular exercise (calisthenics exercise/Indonesian style "Senam Jantung Sehat", walking and jogging program).

In MONICA study, the multistage-stratified-cluster sampling method was performed on population with 523.000 people. 2073 people were included in MONICA study in 1988. From those 2073 people, we recruited only 479 people in the SOK study. Participants were divided into two groups, the group who received SOK intervention (the SOK group) and the group without (the non-SOK group). A complete history of participant including all risk factors was obtained. Physical examination, laboratory examination 
and twelve-lead ECG were performed. The weekly level of physical exercise and/or physical activity (OK) was assessed using the Borg-sport scale. The scale was divided into: 1) no physical activity, 2) lowlevel of OK, 3) medium-level of OK and 4) high-level of OK. ECG was recorded using Minnesota code. Hypertension was classified as recommended by the sixth report (JNC-VI), the Joint National Committee on hypertension. The participant will be diagnosed with diabetes if his/her fasting glucose is $\geq 140 \mathrm{mg} / \mathrm{dl}$ or his/her random glucose is $\geq 200 \mathrm{mg} / \mathrm{dl}$ ). The diagnosis of obesity was based on the BMI value i.e. is $\geq 29,99 \mathrm{~kg} / \mathrm{m}^{2}$. Verbal autopsy was carried out to determine the cause of mortality.

Data were prospectively collected and analyzed with the use of SPSS software (for Window 10) and Stata6 statistical package. Kaplan-Meier survival curves were used to evaluate the survival differences between the two groups. Log-rank test was used to calculate the Hazard Ratio (HR). Degree of agreement was calculated using the kappa test. Comparison among the groups was performed by the t-tests, the Chi- squared test and the Fisher's exact test for categorical data. A value of $p<0.05$ was considered statistically significant. The analysis of variance test was performed for continuous data. Results were expressed as mean value \pm SE. Results were presented as HR and $95 \%$ confidence interval (CI) for each variable. Value with a significance level of $p<0.05$ were accepted as significant.

\section{RESULTS}

Table 1 shows the baseline characteristics of the SOK (479 participants) and the MONICA (2073 participants). The mean age of SOK participants was 46 years (range 25-64) and 270 participants (56\%) were female. SOK participants were somewhat older and have a higher systolic blood pressure. However, those differences had no clinical effects.

As shown in Table 2, 386 participants were entered into the SOK group, whereas 93 participants were entered into the non-SOK group.

Table 1. Baseline characteristics of the SOK study and the 1988 Jakarta-MONICA study

\begin{tabular}{lccc}
\hline & $\begin{array}{c}\text { The 2000 } \\
\text { SOK Study (N=479) }\end{array}$ & $\begin{array}{c}\text { The 1988 } \\
\text { MONICA Study (N=2073) }\end{array}$ & P \\
\hline Age (years) & $46 \pm 0.51^{*}$ & $44 \pm 0.25$ & $0.002^{\dagger}$ \\
Blood pressure (mmHg) & & & $0.016^{\ddagger}$ \\
- Systolic & $126.83 \pm 1.11$ & $123.97 \pm 0.51$ & 0.098 \\
- Diastolic & $79.28 \pm 0.64$ & $78.20 \pm 0.28$ & 0.144 \\
Body weight (kg) & $54.14 \pm 0.48$ & $57.46 \pm 1.09$ & 0.148 \\
Body height (cm) & $153.34 \pm 0.38$ & $156.14 \pm 0.93$ & 0.352 \\
Total cholesterol (mg/dl) & $205.65 \pm 1.89$ & $202.92 \pm 1.34$ & 0.199 \\
Smoking & & & $1140(55.0 \%)$ \\
- Never & $284(59.3 \%)$ & $786(37.9 \%)$ & 0.306 \\
- Yes & $161(33.6 \%)$ & $147(7.1 \%)$ & \\
- Ex- smoker & $34(7.1 \%)$ & & \\
Sport & & $466(22.6 \%)$ & 0.084 \\
- Regularly & $97(20.3 \%)$ & $627(30.2 \%)$ & \\
- Occasional & $138(28.8 \%)$ & $978(47.2 \%)$ & \\
- Never & $244(50.9 \%)$ & $695(33.5 \%)$ & $(15 \%)$ \\
Work load & $137(28.6 \%)$ & $330(15.9 \%)$ & \\
- Low & $253(52.8 \%)$ & & \\
- Medium & $89(18.6 \%)$ & & \\
- High & & & \\
\hline
\end{tabular}

\footnotetext{
${ }^{*}$ Mean and SE, p calculated by t-test and $\mathrm{X}^{2}$-test, ${ }^{\dagger,}{ }^{\ddagger}$ clinically no difference.
} 
Table 2. Baseline characteristics of the SOK-Group and the non-SOK Group

\begin{tabular}{|c|c|c|c|}
\hline \multirow{2}{*}{ Characteristic } & \multicolumn{2}{|c|}{1988} & \multirow{2}{*}{$\mathbf{p}$} \\
\hline & Non-SOK Group $(\mathrm{N}=386)$ & SOK Group $(\mathrm{N}=93)$ & \\
\hline Age (year) & $46+0.58$ & $43 \pm 0.99$ & $0.013^{\#}$ \\
\hline \multicolumn{4}{|l|}{ Blood Pressure (mmHg ) } \\
\hline - Systolic & $126.55 \pm 1.25$ & $127.98 \pm 2.45$ & 0.616 \\
\hline - Diastolic & $78.80 \pm 0.72$ & $81.29 \pm 1.30$ & 0.122 \\
\hline Body weight (kg) & $53.64 \pm 0.53$ & $56.19 \pm 1.10$ & 0.037 \\
\hline Body height $(\mathrm{cm})$ & $153.47 \pm 0.43$ & $152.74 \pm 0.78$ & 0.438 \\
\hline \multicolumn{3}{|l|}{ Blood pressure $(\mathrm{mmHg}) *$} & 0.990 \\
\hline Normal & $228(59.1 \%)$ & $53(57.0 \%)$ & \\
\hline High-normal & $35(9.1 \%)$ & $8(8.6 \%)$ & \\
\hline Grade 1 Hypertension & $70(18.1 \%)$ & $18(19.4 \%)$ & \\
\hline Grade 2 Hypertension & $32(8.3 \%)$ & $9(9.7 \%)$ & \\
\hline Grade 3 Hypertension & $21(5.4 \%)$ & $5(5.4 \%)$ & \\
\hline \multicolumn{3}{|l|}{ Cholesterol (mg/dl) } & 0.205 \\
\hline $102-200$ & $205(53.1 \%)$ & $40(43.0 \%)$ & \\
\hline $201-239$ & $117(30.3 \%)$ & $33(35.5 \%)$ & \\
\hline $240-398$ & $64(16.6 \%)$ & $20(21.5 \%)$ & \\
\hline \multicolumn{3}{|l|}{ Diabetes mellitus } & 0.993 \\
\hline Normal & $361(93.5 \%)$ & $87(93.5 \%)$ & \\
\hline Yes & $25(6.5 \%)$ & $6(6.5 \%)$ & \\
\hline \multicolumn{3}{|l|}{ Body mass index $\left(\mathrm{kg} / \mathrm{m}^{2}\right)^{f}$} & 0.073 \\
\hline $13.79-25.99$ & $308(79.8 \%)$ & $64(68.8 \%)$ & \\
\hline $26.00-29.99$ & $61(15.8 \%)$ & $23(24.7 \%)$ & \\
\hline $30.00-35.58$ & $17(4.4 \%)$ & $6(6.5 \%)$ & \\
\hline \multicolumn{3}{|l|}{ Body mass index $\left(\mathrm{kg} / \mathrm{m}^{2}\right)^{\Psi}$} & 0.008 \\
\hline $13.79-18.50$ & $47(12.2 \%)$ & $5(5.4 \%)$ & \\
\hline $18.50-24.99$ & $235(60.9 \%)$ & $50(53.8 \%)$ & \\
\hline $25.00-26.99$ & $54(14.0 \%)$ & $14(15.1 \%)$ & \\
\hline $27.00-35.58$ & $50(13.0 \%)$ & $24(25.8 \%)$ & \\
\hline \multicolumn{3}{|l|}{ ECG } & 0.219 \\
\hline Normal & $325(84.2 \%)$ & $83(89.2 \%)$ & \\
\hline Abnormal & $61(15.8 \%)$ & $10(10.8 \%)$ & \\
\hline
\end{tabular}

\#Clinically no difference; *normal systolic/diastolic BP $(<130 /<85)$, high-normal $(130-139 / 85-89)$, grade 1 hypertension (140-159/90-99), grade 2 hypertension (160-179/100-109), grade 3 hypertension ( $\geq 180 / \geq 110) ;{ }^{f}$ body mass index-World Health Organization; ' ${ }^{\prime}$ body mass index-Asia; p calculated by X2-test \& Fisher's exact test.

The survival rate of the SOK group was higher compared with the non-SOK group. The non-SOK group had more risk to die (higher HR) than the SOK group, as shown in Figure 1. The cardiovascular-death was lower in the SOK group than the non-SOK group (Table 3).

The mortality rate from cardiovascular (including stroke) was $1.2 \%$ per year (1.200/100.000 population). In Figure 2, the major contribution to the mortality was due to the heart disease (42.9\%).
Modifiable and un-modifiable cardiovascular risk factors with their calculated risk/HR were shown in Table 4. The highest HR was due to hypertension, followed by smoking, diabetes, and obesity respectively. The un-modifiable risks were being fifty years old or older and being male. Thus increased risk to die. Any level of physical exercise and/or physical activity lowered the risk. 


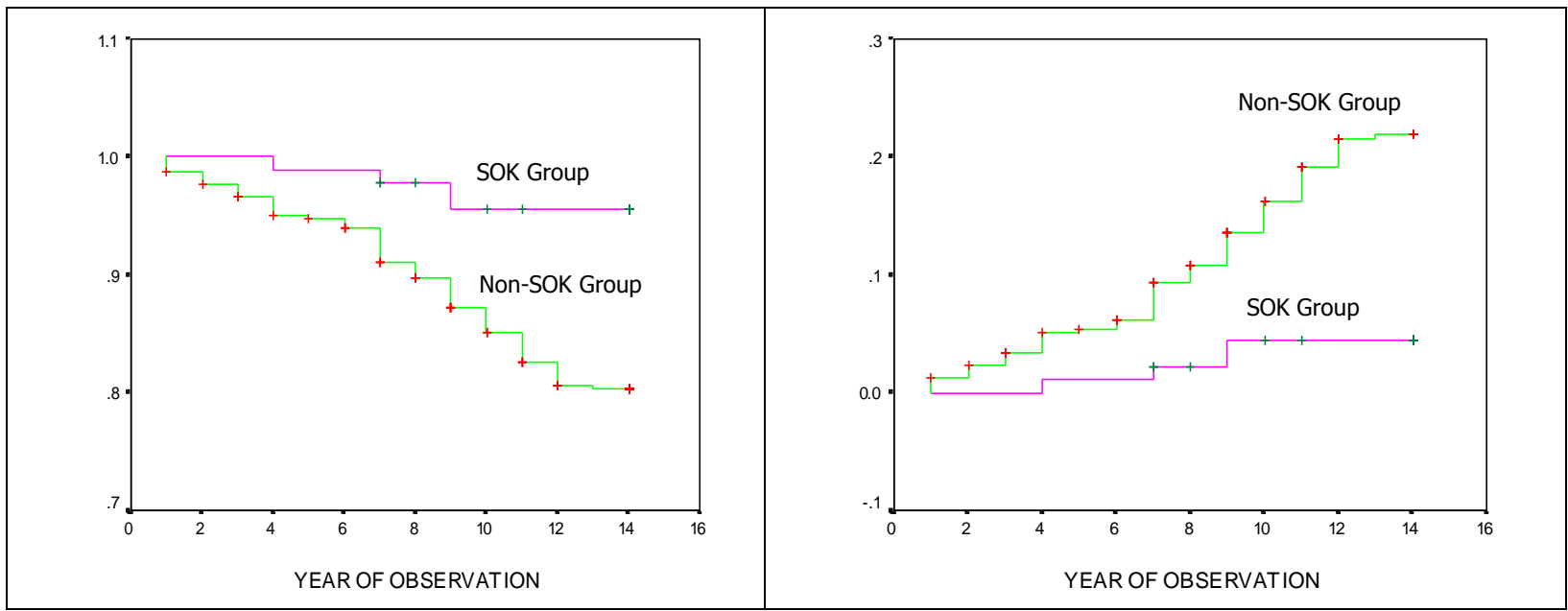

Figure 1. Survival and Hazard-ratio curves between SOK group and non-SOK group

Table 3. Cumulative survival and cumulative death of SOK group and non-SOK group

\begin{tabular}{|c|c|c|c|c|c|c|c|}
\hline \multicolumn{4}{|c|}{ Non-SOK Group } & \multicolumn{4}{|c|}{ SOK Group } \\
\hline $\begin{array}{c}\text { Years of } \\
\text { Observation }\end{array}$ & $\begin{array}{c}\text { Cumulative } \\
\text { Survival }\end{array}$ & $\begin{array}{l}\text { Standard } \\
\text { Error }\end{array}$ & $\begin{array}{c}\text { Cumulative of } \\
\text { Death }\end{array}$ & $\begin{array}{c}\text { Years of } \\
\text { Observation }\end{array}$ & $\begin{array}{c}\text { Cumulative } \\
\text { Survival }\end{array}$ & $\begin{array}{l}\text { Standard } \\
\text { Error }\end{array}$ & $\begin{array}{c}\text { Cumulative of } \\
\text { Death }\end{array}$ \\
\hline 1 & 0.9870 & 0.0058 & 5 & $1-3$ & - & - & 0 \\
\hline 2 & 0.9767 & 0.0077 & 9 & 4 & 0.9892 & 0.0107 & 1 \\
\hline 3 & 0.9662 & 0.0092 & 13 & 7 & 0.9785 & 0.0150 & 2 \\
\hline 4 & 0.9505 & 0.0111 & 19 & $9-13$ & 0.9563 & 0.0214 & 4 \\
\hline 5 & 0.9479 & 0.0114 & 20 & & & & \\
\hline 6 & 0.9399 & 0.0121 & 23 & & & & \\
\hline 7 & 0.9106 & 0.0146 & 34 & & & & \\
\hline 8 & 0.8972 & 0.0156 & 39 & & & & \\
\hline 9 & 0.8728 & 0.0172 & 48 & & & & \\
\hline 10 & 0.8508 & 0.0184 & 56 & & & & \\
\hline 11 & 0.8258 & 0.0197 & 65 & & & & \\
\hline 12 & 0.8062 & 0.0205 & 72 & & & & \\
\hline 13 & 0.8033 & 0.0207 & 73 & & & & \\
\hline \multicolumn{4}{|c|}{$\begin{array}{l}\text { Total sample }=386 \\
\text { Total censored }=313(81.1 \%) \\
\text { Total CV death }=73(18.9 \%) \\
\text { Average survival rate }=12.74,\end{array}$} & \multicolumn{4}{|c|}{$\begin{array}{l}\text { Total sample }=93 \\
\text { Total censored }=89(95.7 \%) \\
\text { Total CV death }=4(4.3 \%) \\
\text { Average survival rate }=13.71,95 \% \text { CI }(13.41-14.00)\end{array}$} \\
\hline
\end{tabular}

$\mathrm{CV}=$ cardiovascular, $\mathrm{CI}=$ Confidence Interval. 


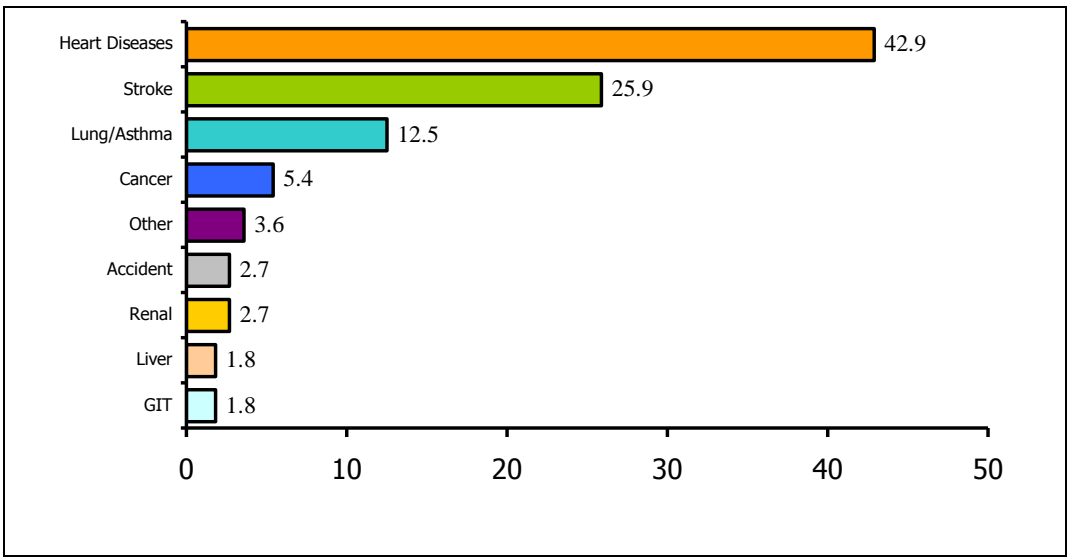

Figure 2. All causes of mortality $(N=112)$.

Table 4. Cardiovascular risk factors and mortality analysis

\begin{tabular}{|c|c|c|c|}
\hline Risk Factor & $\begin{array}{c}\text { Hazard } \\
\text { Ratio }\end{array}$ & $\begin{array}{c}\text { Confidence Interval } \\
(95 \%)\end{array}$ & $\mathbf{P}$ \\
\hline \multicolumn{4}{|c|}{ 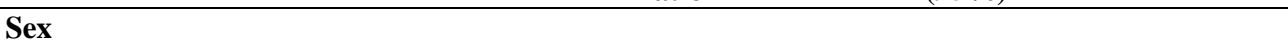 } \\
\hline Female & $1.00 *$ & - & - \\
\hline Male & 1.68 & $0.89-3.18$ & 0.107 \\
\hline \multicolumn{4}{|l|}{ Age (year) } \\
\hline $25-49$ & $1.00 *$ & - & - \\
\hline $50-54$ & 5.63 & $2.51-12.62$ & 0.000 \\
\hline $55-59$ & 5.96 & $2.75-12.92$ & 0.000 \\
\hline $60-64$ & 10.13 & $4.79-21.43$ & 0.000 \\
\hline \multicolumn{4}{|l|}{ Blood Pressure } \\
\hline Normal & $1.00 *$ & - & - \\
\hline High normal & 1.34 & $0.54-3.28$ & 0.527 \\
\hline Grade 1 Hypertension & 1.61 & $0.83-3.14$ & 0.160 \\
\hline Grade 2 Hypertension & 229 & $1.18-4.48$ & 0.015 \\
\hline Grade 3 Hypertension & 5.96 & $2.69-13.21$ & 0.000 \\
\hline \multicolumn{4}{|l|}{ Smoking } \\
\hline Never & $1.00 *$ & - & - \\
\hline Ex-smoker & 4.87 & $1.83-12.97$ & 0.002 \\
\hline Smoker & 4.99 & $2.56-9.73$ & 0.000 \\
\hline \multicolumn{4}{|l|}{ Diabetes Mellitus } \\
\hline No & $1.00 *$ & - & - \\
\hline Yes & 2.74 & $1.37-5.47$ & 0.004 \\
\hline \multicolumn{4}{|l|}{ Body Mass Index $\left(\mathrm{kg} / \mathrm{m}^{2}\right)^{\dagger}$} \\
\hline $13.79-25.99$ & $1.00 *$ & - & - \\
\hline $26.00-29.99$ & 0.85 & $0.48-1.51$ & 0.578 \\
\hline $30.00-35.58$ & 2.18 & $0.94-5.10$ & 0.071 \\
\hline \multicolumn{4}{|l|}{ Physical Exercise/Activity } \\
\hline No & $1.00 *$ & - & - \\
\hline Low & 0.45 & $0.27-0.76$ & 0.003 \\
\hline Medium & 0.32 & $0.15-0.70$ & 0.004 \\
\hline High & $\mathrm{UC}^{*}$ & - & - \\
\hline
\end{tabular}

$*$ Used as reference, ${ }^{\dagger}$ World Health Organization criteria, ${ }^{\ddagger} \mathrm{UC}=$ uncountable. $\mathrm{p}$ calculated using Cox regression analysis. 
We discovered the formula to predict the survival as follow:

$$
\begin{gathered}
\mathbf{S}(\text { years })=[\mathbf{S 0}(\mathbf{t})] \mathbf{e}^{\boldsymbol{f}} \\
f=\Sigma(\beta \times \text { gender })+(\beta \times \text { age })+(\beta \times \mathrm{BP})+(\beta \times \mathrm{S})+(\beta \times \mathrm{BS})+(\beta \times \mathrm{BMI})+(\beta \times \mathrm{OK})
\end{gathered}
$$

The ten years probability to survive is formulated as follow:

$$
S(10 \text { year })=[\operatorname{SO}(t)] \mathrm{e}^{(\beta \times \text { gender })+(\beta \times \text { age })+(\beta \times \text { BP })+(\beta \times S)+(\beta \times \text { BS })+(\beta \times \text { BMI })+(\beta \times \text { OK })}
$$

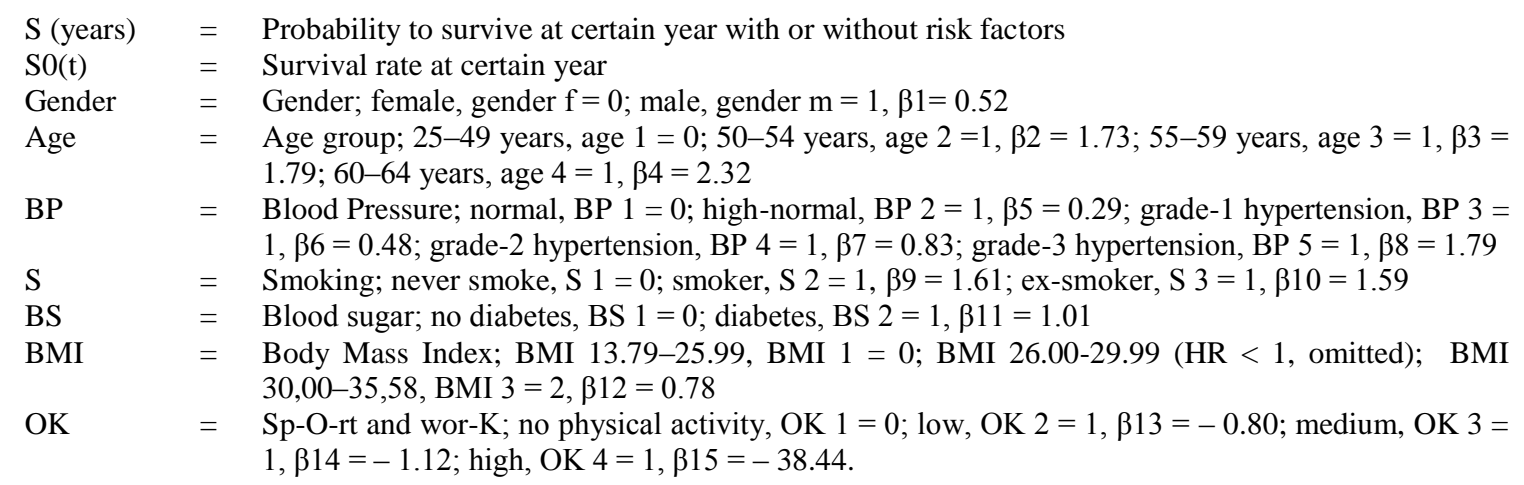

Based on Framingham model on cardiovascularscoring, we created our own score, the Jakarta Cardiovascular Score, which is practical and can be implemented in our own community (Table 5).

\section{DISCUSSION}

The mortality rate from cardiovascular (including stroke) in the SOK study was $1.2 \%$ per year $(1.200 / 100.000)$, which is similar to South India (1.3\%). But was significantly lower compared to the Framingham (8.5\%). The report from China showed lower rate from heart disease but higher rate from stroke.

The survival rate of the SOK group was better than the non-SOK group $(95.7 \%$ vs $81.1 \%)$ ( $p=0.001$ ). None of the participants from SOK group died in the first four years of follow up. The HR of the SOK group was one fifth of the non-SOK group (relative hazard ratio $=0.20 ; 95 \%$ CI $0.08-0.57 ; \mathrm{p}=0.002$ ) The benefit of SOK was observed as early as the first year of intervention (Figure 1 and Table 3).

From SOK study, we determined modifiable risk factors, which contributed to the mortality. Our data were similar with previous findings from others countries.
Smoker and ex-smoker have higher HR compared to never smoke or already quit for 10 years or more. Therefore, it is reasonable to advise someone never to smoke or to encourage quitting permanently. Say no to smoking is part of the modern way of life to improve survival (Figure 3).

The participants who were entered into the SOK group was never smoke or already quitting for 10 years or more. This criteria was adopted from Framingham study combined with recent study by Samet JM. ${ }^{24}$ From univariate logistic regression analysis, it can be shown that the younger the participant smoked, the higher his HR. Other important finding was the type of cigarette; clove smoker had higher HR compared to usual smoker. Smoker in this study was defined as a person who continued to smoke or quitted less than 2 years, adopted from criteria used in other studies. ${ }^{24,25}$ It is encouraging to see that prevalence of smoking had reduced both in male and female as a result of our ongoing anti-smoking campaign raged in the area. However, till the present time the obstacle of the campaign has been with the successful multimedia advertising and the unsupportive government policy. 
Table 5. The Framingham Score and the Jakarta Cardiovascular Score

\begin{tabular}{cccc}
\hline \multicolumn{3}{c}{ Framingham Score } \\
\hline \multirow{2}{*}{ Risk Factor } & \multicolumn{2}{c}{ Score } \\
\cline { 2 - 3 } & Male & Female \\
\hline Age & & \\
$<35$ & -1 & -9 \\
$35-39$ & 0 & -4 \\
$40-44$ & 1 & 0 \\
$45-49$ & 2 & 3 \\
$50-54$ & 3 & 6 \\
$55-59$ & 4 & 7 \\
$60-64$ & 5 & 8 \\
$65-69$ & 6 & 8 \\
$70-74$ & 7 & 8 \\
& & &
\end{tabular}

\begin{tabular}{|c|c|c|}
\hline \multicolumn{3}{|c|}{ Total Cholesterol (mg/dl) } \\
\hline$<160$ & -3 & -2 \\
\hline 169-199 & 0 & 0 \\
\hline $200-239$ & 1 & 1 \\
\hline $240-279$ & 2 & 2 \\
\hline$\geq 280$ & 3 & 3 \\
\hline \multicolumn{3}{|c|}{ HDL-Cholesterol (mg/dl) } \\
\hline$\geq 60$ & -2 & -3 \\
\hline$\overline{5} 0-59$ & 0 & 0 \\
\hline $45-49$ & 0 & 1 \\
\hline $35-44$ & 1 & 2 \\
\hline$<35$ & 2 & 5 \\
\hline \multicolumn{3}{|c|}{ Systolic Blood Pressure } \\
\hline$<120$ & 0 & -3 \\
\hline $120-129$ & 0 & 0 \\
\hline $130-139$ & 1 & 1 \\
\hline $140-159$ & 2 & 2 \\
\hline$\geq 160$ & 3 & 3 \\
\hline \multicolumn{3}{|c|}{ Diabetes Mellitus } \\
\hline No & 0 & 0 \\
\hline Yes & 2 & 4 \\
\hline \multicolumn{3}{|l|}{ Smoking } \\
\hline No & 0 & 0 \\
\hline Yes & 2 & 2 \\
\hline
\end{tabular}

\begin{tabular}{|c|c|}
\hline \multicolumn{2}{|c|}{ Jakarta Cardiovascular Score } \\
\hline Risk Factor & Score \\
\hline \multicolumn{2}{|l|}{ Sex } \\
\hline Female & 0 \\
\hline Male & 1 \\
\hline \multicolumn{2}{|l|}{ Age } \\
\hline $25-34$ & -4 \\
\hline $35-39$ & -3 \\
\hline $40-44$ & -2 \\
\hline $45-49$ & 0 \\
\hline $50-54$ & 1 \\
\hline $55-59$ & 2 \\
\hline $60-64$ & 3 \\
\hline
\end{tabular}

\begin{tabular}{ll}
\hline Blood Pressure* & \\
Normal & 0 \\
High Normal & 1 \\
Grade 1 Hypertension & 2 \\
Grade 2 Hypertension & 3 \\
Grade 3 Hypertension & 4 \\
& \\
\hline Body Mass Index $\left(\mathbf{k g} / \mathbf{m}^{2}\right)$ & \\
13.79-25.99 & 0 \\
$26.00-29.99$ & 1 \\
$30.00-35.58$ & 2
\end{tabular}

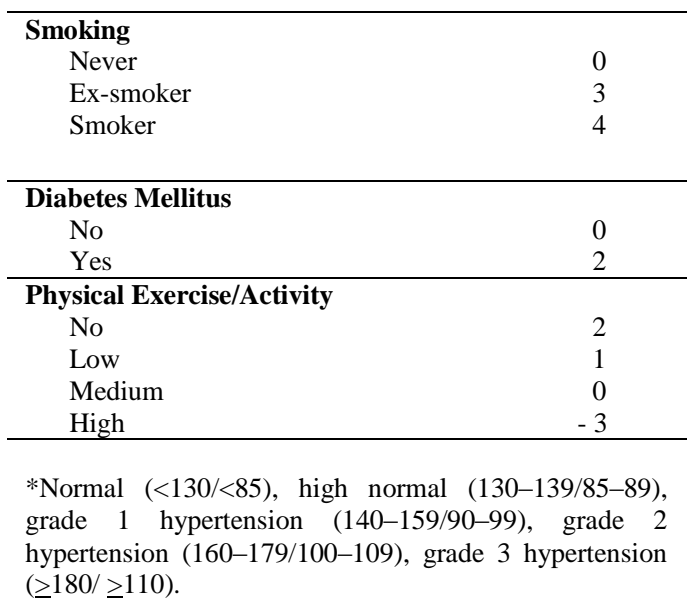

The Jakarta Cardiovascular Score; sensitivity $77.9 \%$, specificity $90.0 \%$, positive predictive value $92.2 \%$, negative predictive value $72.8 \%$, degree of agreement $82.67 \%$, kappa $0.652, \mathrm{p}=0.000$; the score between -7 to $1 \rightarrow$ low risk $\left(\mathrm{CV}^{10}<10 \%\right)$, the score between 2 to $4 \rightarrow$ moderate risk $\left(\mathrm{CV}^{10}=10-20 \%\right)$, the score $\geq 5 \rightarrow$ high risk $\left(\mathrm{CV}^{10}>20 \%\right), \mathrm{CV}^{10}-$ the cardiovascular event in ten-years time.

In Figure 4 and Figure 5, hypertension and diabetes had been shown to be the major risk factors. Likewise, various studies have proven that controlling both blood pressure and blood glucose to normal level using various medications will reduce the cardiovascular events. We concluded in this study that keeping the blood pressure as normal as possible and monitoring blood glucose level as tight as possible will be a rational way to enhance survival. Obesity namely BMI is $\geq 30,00 \mathrm{~kg} / \mathrm{m}^{2}$, in our study was not considered to be a significant risk. However, it is reasonable to advise someone to keep their ideal weight, based on multiple studies, which showed the hazard of being obese. In this study, the prevalence of obesity in female was higher than male. If physical exercise/physical activity is insufficient to maintain ideal weight, the dietary program should then be introduced. 


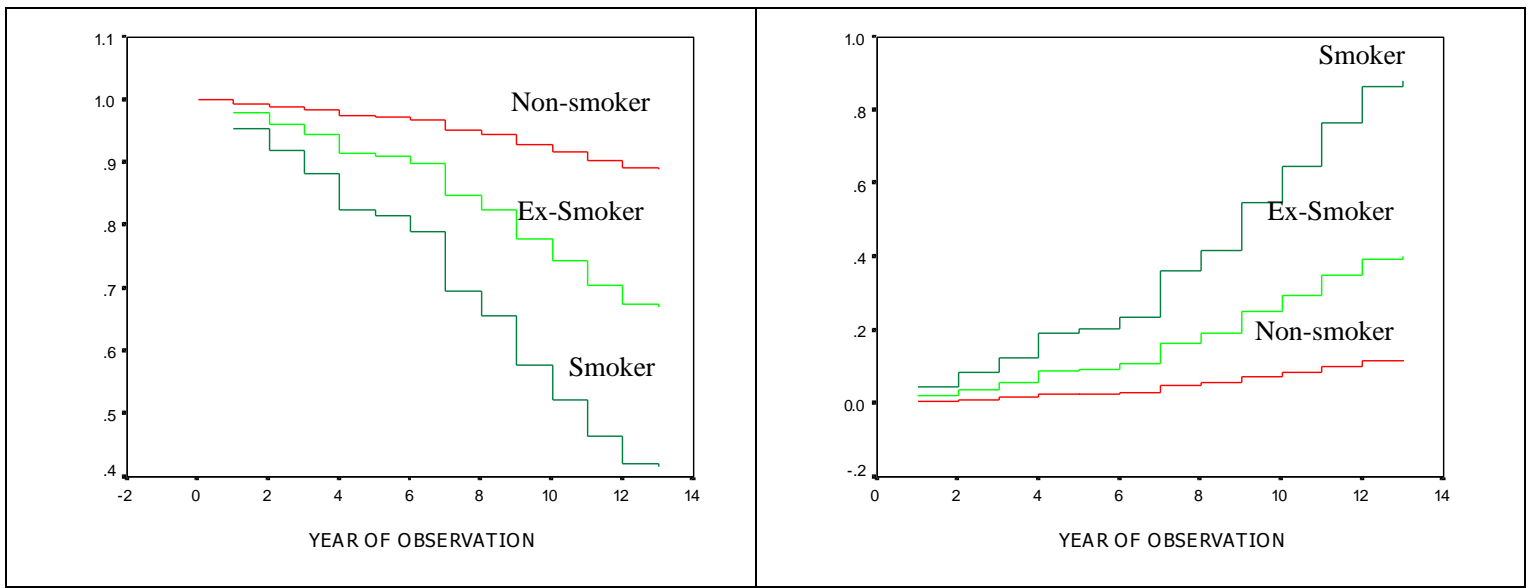

Figure 3. Survival curve and Hazard Ratio of smoking
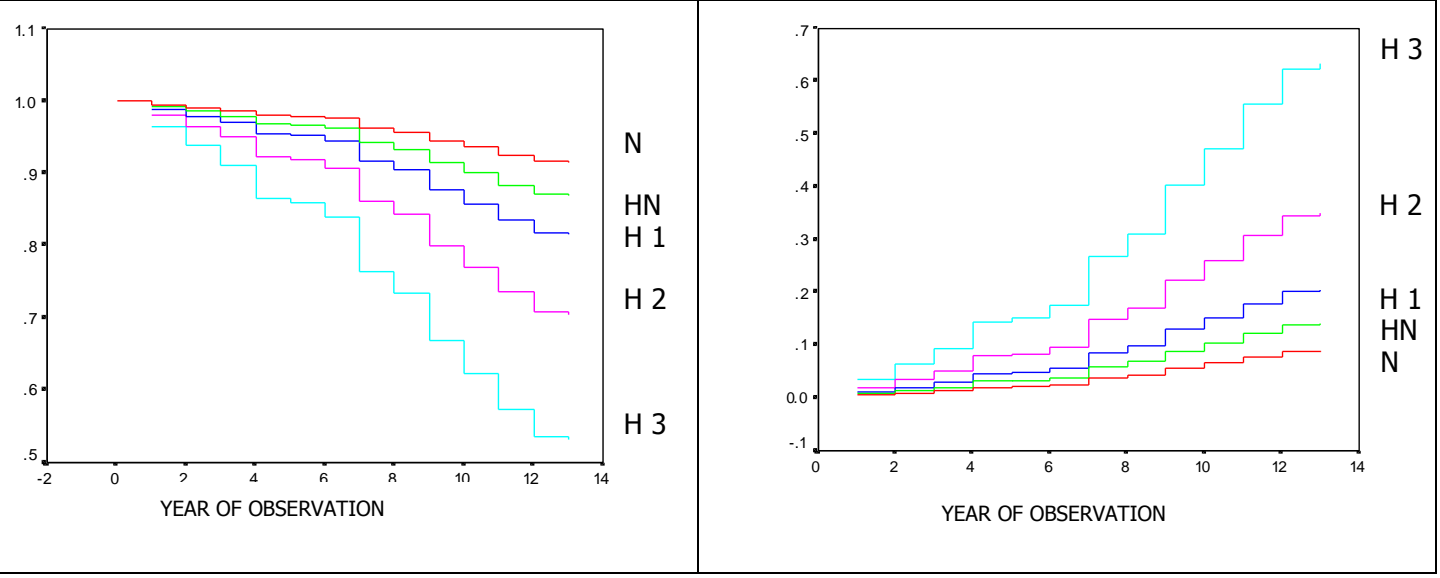

Figure 4. Survival curve and Hazard Ratio of hypertension. (N=Normal, HN=High Normal, HI=Grade 1 Hypertension, $H 2=$ Grade 2 Hypertension, $H 3=$ Grade 3 Hypertension)

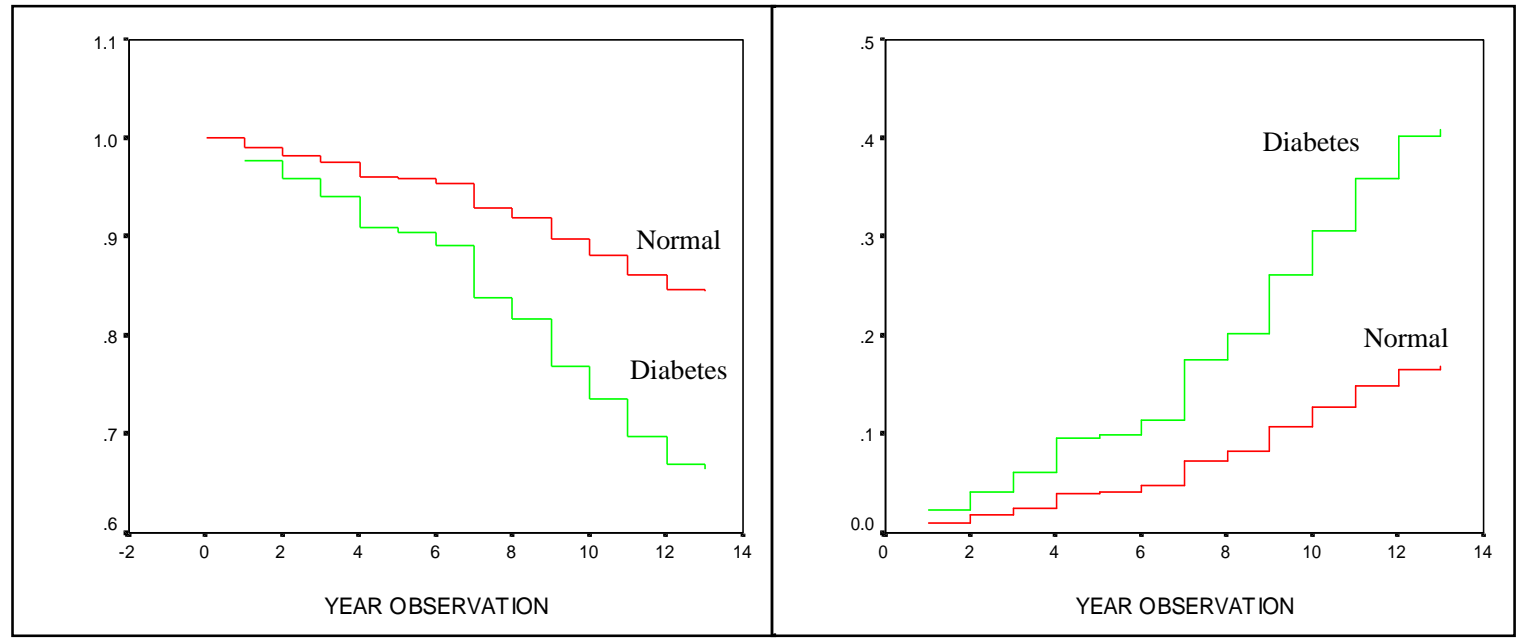

Figure 5. Survival curve and Hazard Ratio of diabetes 
Being physically active is a nature gift from God, the Creator of the rotated universe. Any physical exercise/physical activity, low/medium or high, as long as performed regularly, few times a week, will decrease the mortality rate by half (relative HR between 0 to 0.45 ). So, more activity will increase chance to survive, as shown in Figure 6. Regular physical exercise/physical activity (medium or high level) performed 2 to 3 times a week will have similar benefit compare with regular daily physical activity. But low- level physical exercise/physical activity, aimed at increasing heart rate by ten beats per minute, will also give protection but it has to be practiced everyday. So far, we have developed various exercise programs. The most practical/most economical type of sport is $6 \mathrm{~km}$ walking for one hour, done regularly several times a week. Other types included aerobic dancing (Indonesian "Senam Jantung Sehat"), traditional dancing and martial arts (Indonesian "Pencak Silat", karate and others). Other activity such as stepping on two stairs, carrying ten kgs of weight and gardening is also good enough to prevent cardiovascular disease. In a simple way, all kind of activities aiming to increase heart rate between 110 130 beats per minute, at the same time also increases respiratory rate and produces sweating has preventive effect against heart disease and stroke.

Looking at the result of our study, the most reliable programs in the community should be with the antismoking campaign and keeping the blood pressure as normal as possible. For hypertensive patient, we at least should target the blood pressure to 140/90 $\mathrm{mmHg}$. Although at this level the HR was still relatively high (1.61). Un-modifiable risk factor, age 50 years or above, has higher risk for cardiovascular events compared to younger age (Figure 7). This finding is not surprising, since aging process will promote atherosclerosis. Male compared with female, has higher risk for cardiovascular events and lower rate of survival. This is supported by Framingham study.

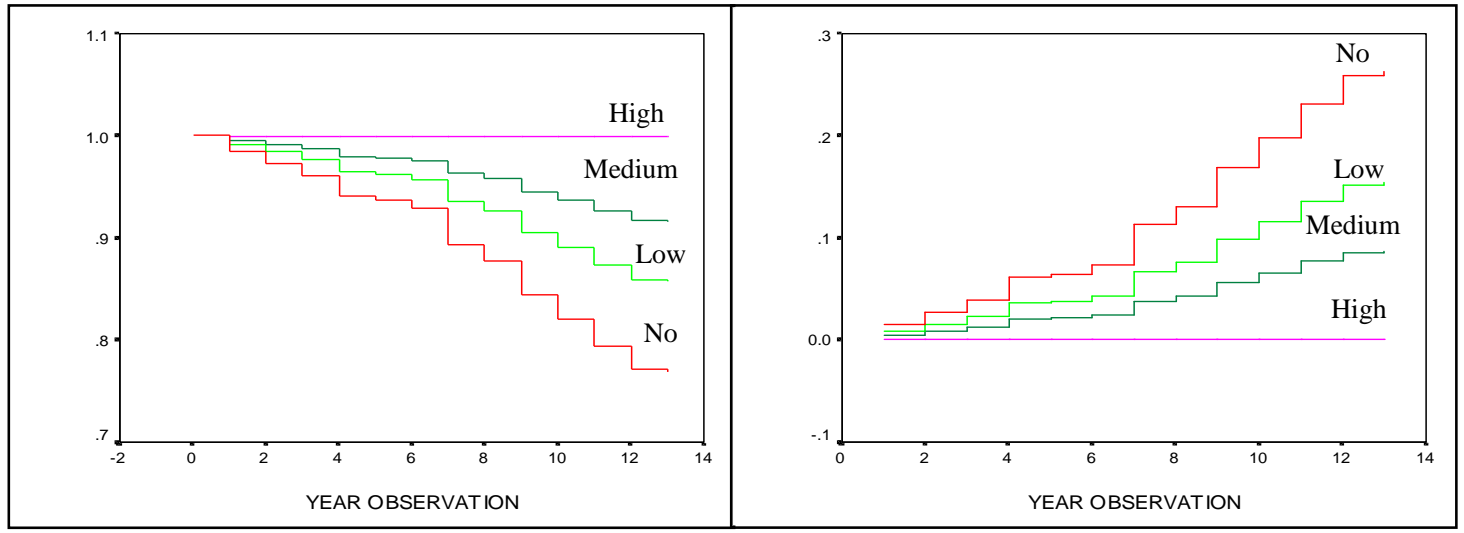

Figure 6. Survival rate and Hazard Ratio of physical activity

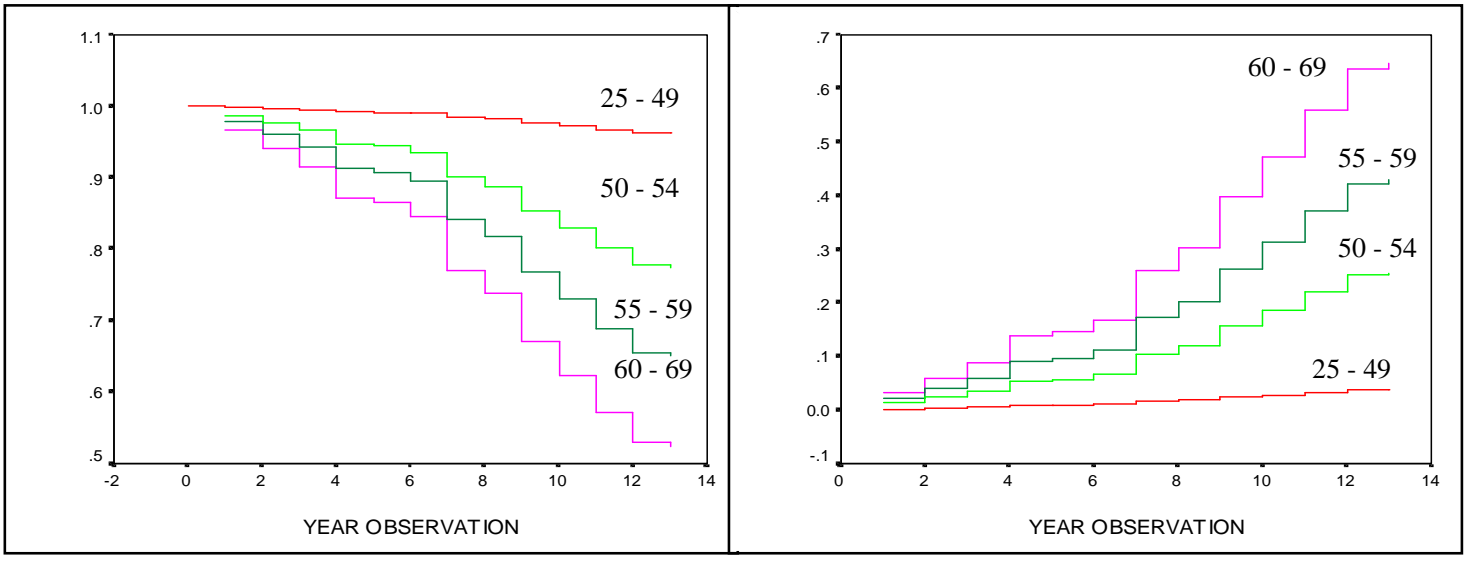

Figure 7. Survival rate and Hazard ratio of age group 
From this study, we successfully developed our own score, the Jakarta Cardiovascular Score. The score is to predict the ten years risk for cardiovascular events, namely $\mathrm{CV} .{ }^{10}$ The score was derived from the Framingham score and adjusted accordingly for our community. With this score, anyone can participate in the preventative program to enhance his/her survival, i.e. by reducing all-modifiable risk factors.

\section{CONCLUSIONS}

In conclusion, the results of the SOK study strongly suggest that SOK intervention increases survival. The method is simple and can be implemented in the community.

Cardiovascular prevention must be the national firstpriority. The Indonesian- Government should take legal action against smoking campaign and should support the healthy life-style program for example: encourage people to do more exercise/increase their physical activity and perhaps build more community sport-facilities.

\section{Acknowledgments}

The author would like to thank Prof. dr. Ali Sulaeman, $\operatorname{Sp} . \operatorname{PD}(\mathrm{K}), \mathrm{PhD}$, the Dean of Faculty of Medicine, University of Indonesia; Prof. dr. Asikin Hanafiah, $\operatorname{Sp} . \mathrm{A}(\mathrm{K})$, Sp.JP(K), the Principal-supervisor of doctoral degree; Prof. Dr. dr. Bambang Sutrisna, MHSc (the Cosupervisor of doctoral degree); Prof. Dr. dr. Agus Firmansyah, Sp.A(K); Prof. dr. Boedhi-Darmojo, $\operatorname{Sp} . \operatorname{PD}(K)$, Sp.JP(K); Prof. dr. Nurhay Abdurachman, $\operatorname{Sp.PD}(\mathrm{K})$, Sp.JP(K); Prof. Dr. Harsuki, MA; dr. Sutarmo Setiadji, PhD; Prof dr Bastaman Basuki, MPH; dr. Otte J. Rachman, Sp.JP(K), the Head of the Cardiology Department/ Harapan Kita National Cardiovascular Centre; dr. Aulia Sani, Sp.JP(K), FJCC, the Director of Harapan Kita National Cardiovascular Centre; all community doctors from the district hospitals - Mampang Prapatan, Cilandak and Kebayoran Baru; the investigator team of the MONICA Jakarta project; all colleagues, cardiology residents, nurses, paramedics, healthpersonnel for their valuable support and participation for this study and during my promotion for doctoral degree.

\section{REFERENCES}

1. Reddy KS, Yusuf S. Emerging epidemic of cardiovascular disease in developing countries. Circulation 1998;97:596601.
2. Djaja S, Soemantri S, Miharja L, Setyowati T. Pola sebab kematian di Indonesia. Survei Kesehatan Rumah Tangga (SKRT). Badan Litbangkes Departemen Kesehatan RI; 1995.

3. Miharja L, Soemantri S, Djaja S, Setyowati T. Mortalitas penyakit kardiovaskular serta beberapa faktor risiko yang berkolerasi. Seri Survei Kesehatan Rumah Tangga; 1997.

4. Kannel WB, McGee DL, Castelli WP. Latest perspective on cigarette smoking and cardiovascular disease. The Framingham study. J Cardiac Rehab 1984;4:267-77.

5. Levy D, Wilson PWF, Anderson KM, Castelli WP. Stratifying the patient at risk from coronary disease. New insights from the Framingham Heart Study. Amer Heart J 1990;119 (suppl 3):712-17.

6. Pepine CJ, Drexler H, Dzau VJ. Endothelial function in cardiovascular health and disease. Division of CV Med Univ of Florida College of Med, Florida, USA; 1997. p.440.

7. Uematsu M, Ohara Y, Navas JP, Nishida K, Murphy TJ, et al. Regulation of endothelial cell nitric oxide synthase mRNA expression by shear stress. Am J Physiol 1995;269 (6pt1):C1371-78.

8. Kelly RA, Smith TW. Nitric oxide and nitrovasodilators: Similarities, differences and interactions. A Morris JN, Heady JA, Raffle PAB, Roberts CG, Parks JN. Coronary heart disease and physical activity of work. Lancet 1953;2:1053-57,1111-12.

9. Boedhi-Darmojo R, Karim S, Sutedjo, Setianto B, Kusmana D, dkk. MONICA Jakarta survei kedua 1993/1994 dalam: Sutedjo dkk. Presentasi dan diskusi survei II MONICA Jakarta 1993; 1994 Des 20; Jakarta; Badan Litbang Depkes RI, Pusat Kesehatan Jantung Nasional RS. Jantung Harapan Kita: 1994.

10. Kusmana D. Faktor risiko koroner di Indonesia. Buku kumpulan makalah simposium panel strategi penanggulangan penyakit jantung koroner; 1987 Juli 21; Jakarta: FKUI; 1987.

11. Gotto A, Pownall H. Manual of lipid disorders. Baltimore: William \& Wilkins; 1999. p.60-335

12. Berliner JA, Navab M, Fogelman AM, Franks JS, Demer LL, Edwards PA, et al. Atherosclerosis: Basic mechanism, oxidation, inflamation and genetics. Circulation 1995; 91:2488-96.

13. Kuhn H, Chan L. The role of 15-lipoxygenase in atherosclerosis: Pro-and anti atherogenic action. Curr opin lipidol 1997;8:111-17.

14. Sigari F, Lee C, Witzum JL, Reaven PT. Fibroblasts that overexpress 15-lipoxygenase generate bioactive and minimally modified LDL. Arterioscler thromb vasc biol 1997; 17:3639-45.

15. Falk E, Shah PK, Fuster V. Pathogenesis of plaque disruption, in: Fuster V, Ross R, Topol EJ. Atherosclerosis and coronary artery disease. Philadelphia: Lippincott-Reaven; 1996. p. 491-507.

16. Misbach J, Andradi S, Malik MS, Sandia IN. Laporan penelitian survei stroke di Jakarta suatu awal penelitian masalah stroke di Indonesia menjelang tahun 2000. Depkes RI; 2001.

17. Misbach J. Pattern of hospitalized-stroke patients in ASEAN countries an ASNA stroke epidemiological study. Med J Indones 2001;10:48-56. 
18. Rubanyi GM, Romero JC, Vanhoutte PM. Flow-induced release of endothelium derived relaxing factor. Am J Physiol 1986;250:822-27.

19. Joanides R, Haefeli WE, Linder L, Richard V, Bakkali $\mathrm{EH}$, Thuillez $\mathrm{C}$, et al. Nitric oxide is responsible for flow - dependent dilatation of human peripheral conduit arteries in vivo. Circulation 1995;91(5):1314-19.

20. Ekblom, B. Et al. Effect of training on circulatory response to exercise. J Appl Physiol 1968;24:518.

21. Kusmana D. Olahraga bagi kesehatan jantung. Balai Penerbit FKUI; 2000.

22. William D. McArdle, Frank I. Katch, Victor L. Katch. Exercise physiology. Energy, nutrition, and human performance. Lea \& Febiger; 1981. p.219-233.
23. Borg. G and Liderholm. H. Perceived exertion and pulse rate during graded exercise in various age groups. Acta Med Scand 1967;(S)472:194.

24. Samet JM, Yoon SY. Women and the tobacco epidemic; Challenges for the $21^{\text {st }}$ century. Canada: the WHO in collaboration with the Institute for Global Tobacco Control Johns Hopkins School of Public Health; 2001. p.18-45.

25. Omenn GS, Anderson KW, Kronmal RA, et al. The temporal pattern of reduction of mortality risk after smoking cessation. Am J Prev Med 1990;6:251-7. 
Synopsis:

D. Kusmana

The influence of smoking cessation, regular physical exercise and/or physical activity on survival: a $\mathbf{1 3}$ years cohort study of the Indonesian population in Jakarta

Endothelial dysfunction, the beginning of atherosclerosis, is caused by various risk factors. Prevention is by intervening the modifiable risk factors; smoking cessation, regular physical exercise (sport) and/or regular physical activity, the SOK(S-top/no Smoking, sp-O-rt, wor-K/ physical activity). SOK, is a simple method for community prevention against cardiovascular death. 